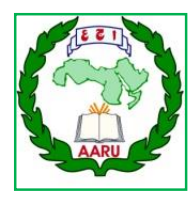

Arab Univ. J. Agric. Sci., Ain Shams Univ., Cairo, Egypt

28(2), 685-694, 2020

Website: http://ajs.journals.ekb.eg

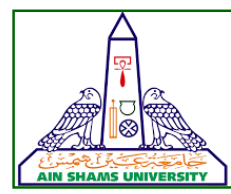

685

\title{
QUANTIFYING THE HYDRAULIC PROPERTIES OF SOME EGYPTIAN SOILS USING RETC CODE
}

Talat $^{1^{\star}}$ A.E., Saad El-Dein ${ }^{1}$ A.A., Arafa ${ }^{2}$ Y.E. and Galal ${ }^{1}$ M.E.

1- Soil Sci. Dept., Fac. of Agric., Ain Shams Univ., P.O. Box 68, Hadayek Shoubra 11241, Cairo, Egypt

2- Agric. Engineering Dept., Fac. of Agric., Ain Shams Univ., P.O. Box 68, Hadayek Shoubra 11241, Cairo, Egypt

*Corresponding author: ahmed ehab2257@yahoo.com

Received 12 May, 2020

Accepted 5 July, 2020

\section{ABSTRACT}

Temporal and spatial soil variabilities reduce the accuracy of quantifying the hydraulic properties of the soil, leading to poor irrigation management. Modeling estimation and computer codes (e.g., RETC code) have been used to quantify and predict soil hydraulic properties. One hundred soil samples were collected to represent soil textural classes according to USDA textural triangle. Following the physical, chemical and hydraulic characterization of the soil samples collected, one soil sample was chosen to represent each texture class. The selected soil samples covered six USDA textural classes. Then, Brooks-Corey (B-C) (1964) and van Genuchten (vG) (1980) parametric models were used to describe the functional relationship between soil water tension and water content, i.e. the soil water retention curve, and the Mualem (1976) theoretical models of pore size distribution were used to predict the functions of unsaturated conductivity $\mathrm{K}$ $(\theta)$ and soil water diffusivity $D(\theta)$. The RETC (retention curve) code was used to obtain the parameters of $\mathrm{VG}$ and $\mathrm{B}-\mathrm{C}$ models by simultaneously matching to the observed data. Output file of refining process showed the iteration levels to achieve minimum value of residual summed square (RSSQ).

The values of determination coefficient $\left(R^{2}\right)$ of the fitted $\theta(h)$ as a power function increased after fitting the experimental data either in $\mathbf{B}-\mathbf{C}$ or in $\mathbf{v G}$ models. The values of $R^{2}$ of the fitted equation of $\theta$ (h) with both B-C and vG data increased after refining process through RETC code. The increments of $R^{2}$ values after refining are more pronounced in coarse textured samples (Sand, Loamy sand, and Sandy loam).
The values of determination coefficient $\left(R^{2}\right)$ of the fitted functions $K(\theta)$ and $D(\theta)$ as a power function are highly significant after fitting soil parameters either in B-C or in vG models. While using RETC code refined the obtained soil parameters of both $K$ $(\theta)$ and $D(\theta)$ increasing $R^{2}$ values of fitted power function and reducing residual summation square. RETC reduced the value of residual summed square (RSSQ) of the objective function $\mathbf{O}(\mathbf{b})$ under using both B-C and VG models. This reduction of RSSQ by using RETC fluctuated between $60.4 \%$ and $98.2 \%$ with B-C for six soil textural classes. While, the reduction of RSSQ by using RETC fluctuated between $90.4 \%$ and $98.6 \%$ with vG for the same six soil textural classes. In general, the RETC code is a good tool for obtaining accurate values of hydraulic properties in a variety of soil textures.

Keywords: Soil hydraulic properties, Soil water retention, Hydraulic conductivity, RETC.

\section{INTRODUCTION}

Water shortage are a growing global issue that threatens sustainable development and even the existence of human kind in some parts of the world. The fast-growing population and limited water supplies in arid regions were the main causes of water scarcity. The trend of using numerical models to research and management is likely to be continuing as the cost of computers keeps decreasing and the need for forecasting with higher precision increases. Amounts of water for irrigation depend on certain soil hydraulic properties, e.g., field capacity, wilting point and available water. 
Water behavior in the soil is fluctuated between retention and movement. Hydraulic conductivity and water retention properties are the determining characteristics that control the behavior of water flow systems. The soil hydraulic conductivity $K(\theta)$ is an indicator of its capacity to move; water retention curve $\theta(h)$ is an expression of its water storage capacity (Nasta et al 2013).

Soil hydraulic properties can be measured through direct methods or estimated by indirect approaches. There are many direct methods to obtain soil hydraulic properties, nevertheless such techniques are expensive and difficult to execute almost without exception (Schindler et al 2015; Patil et al 2016). Determination of $\theta(h)$ may be done in laboratory with a pressure cooker and a pressure membrane (Iden et al 2015), and its in-situ measurement requires the simultaneous measurement of both the water content and pressure head with neutron scattering or gamma ray attenuation observations.

In sharp contrast to direct methods for measuring the hydraulic properties, relatively little attention is being paid to the development of indirect methods which estimate hydraulic properties from more easily measured data, including bulk density, organic matter content or cation exchange capacity, clay minerals and some soil structure parameters, known as pedotransfer functions.,(Bohne et al 2000; Gimenz et al 2001; Nguyen, 2016; Soldi and Jougnot, 2017; Borek et al 2018 and Londra and Kargas, 2018).

The soil water content and unsaturated hydraulic conductivity $(\mathrm{K})$ are determined and this approach is used to evaluate the parameters $(\theta r, \theta s$, $\alpha, m, n$ ). Three designs (van Genuchten-Mualem $m$ $=1-1 / \mathrm{n}$, van Genuchten-Burdine $\mathrm{m}=1-2 / \mathrm{n}$ and Brooks \& Corey $n \rightarrow \infty$ ) are fitted with soil moisture retention data using the RETC code. Three models gave an excellent description of moisture data as van Genuchten model, Mualem model ( $m=1-1 / n)$ was superior to other models with the highest determination coefficient $R^{2}=0.9843$ and the lowest sum of the residual squares $S S Q=0.0031$., (Kadhim, 2011).

RETC is a computer code for studying the dynamics of water soil storage. The water retention curve, $\theta(h)$, in line with the formula of van Genuchten, has five unknown parameters: $\theta s, \theta r, \alpha, n$, and $\mathrm{m}$. The predictive equation for the hydraulic conductivity $\mathbf{I}$ and $\mathbf{K}_{\mathbf{s}}$ is shown. Thus, hydraulic functions have seven independent parameters $\mathbf{b}=(\theta \mathrm{s}, \theta \mathrm{r}, \alpha$, $\mathrm{n}, \mathrm{m}, \mathrm{l}, \mathrm{Ks}$ ). The RETC code can be used to get some, or most of these parameters by simultaneously matching with the observed data.
The objective of this research is to obtain accurate values of hydraulic soil properties under different soil textures.

\section{MATERIALS AND METHODS}

To obtain specific soil hydraulic properties values e.g., Soil water retention characteristics $\theta(h)$, unsaturated hydraulic conductivity $\mathrm{K}(\theta)$ and soil water diffusion $D(\theta)$ soil samples were collected from three locations to reflect the different soil textures, Table (1).

Table 1. Location and coordinates of the collected soil samples.

\begin{tabular}{|c|l|c|c|}
\hline $\begin{array}{c}\text { Sample } \\
\text { No. }\end{array}$ & \multicolumn{1}{|c|}{ Location } & $\mathbf{N}^{\circ}$ & $\mathbf{E}^{\circ}$ \\
\hline $\mathbf{1}$ & El-Ismailia Governorate & 301015 & 333242 \\
$\mathbf{2}$ & 302606 & 320302 \\
\hline $\mathbf{3}$ & El-Sharkiya Governorate & 301929 & 315034 \\
$\mathbf{4}$ & 302738 & 315430 \\
\hline $\mathbf{5}$ & Qalubiya Governorate & 301803 & 311924 \\
$\mathbf{6}$ & 302029 & 315038 \\
\hline
\end{tabular}

\section{Sampling sites and soil samples}

One hundred of both disturbed and undisturbed surface soil samples were collected (depth 0-30 cm) and characterized using the standard methods described in Page, ed. (1982) and Klute, ed. (1986).

\section{Determination of hydraulic soil properties for selected samples}

All of the studied soil samples were saturated with water once, and suctions were applied to the sandy box instrument (under low pressure heads, 10, 30 and 100 mbar).In addition, saturated soil samples were also tested in highly pressurized apparatus, i.e. pressure cooker and pressure membrane $(300,600,1000,3000,5000,10000$ and 15000 mbar) according to (Klute, 1986). Theoretically, all the pores in the soil are filled with water after saturation, so the total porosity indicates the percentage of soil saturation. But, to simplify the mathematics processing and formulation of predictive equations, it is assumed that the soil water content at saturation $\boldsymbol{\theta}_{0.01}$ mbar.

The saturated hydraulic conductivity was calculated according to Darcy's law using the fixed-head technique: 
$Q / A t=K$ sat $\Delta H / L$

Where: $Q$ is the amount of outflow water at the time flowing through the column of soil $\left(\mathrm{cm}^{3}\right), A$ is the cross-sectional area of the column of soil $\left(\mathrm{cm}^{2}\right), \Delta \mathrm{H}$ / $\mathrm{L}$ is the hydraulic gradient, Ksat is the saturated hydraulic conductivity.

The $K(\theta)$ and $D(\theta)$ functions are estimated from the measured data $\theta(h)$ based on the Brooks and Corey (1964) and van Genuchten (1980) models.

\section{Selection processing of soil samples}

The parameters obtained for both models underwent refining using the RETC code with the theoretical pore distribution model derived from (Mualem, 1976).

RETC uses the least square nonlinear optimization approach to estimate unknown model parameters of retention and conductivity function. The aim of the curve-fitting process is to find an equation that minimizing the residual sum of squares, SSQ. The value of the residue squares represents the degree of bias (inconvenience) and random error contributions. SSQ is referred to as the object function $\mathbf{O}(\mathbf{b})$, where $\mathbf{b}$ represents the parameter of the unknown vector. RETC minimizes $\mathbf{O}(\mathbf{b})$ by the weighted least square method. The elements bj of the parameter vector $\mathbf{b}$ are updated sequentially during each iteration step, and the model results are compared with those obtained at the previous iteration level, Yates et al (1992).

\section{Statistical decisions and analyzes}

The determination coefficient (denoted by the symbol $R^{2}$ ) is calculated to indicate how close the data is to the appropriate regression line. The closer the value is to 1 , the better the relationship between the two factors. The determination coefficient is the square of the correlation coefficient, also known as "R," which allows the degree of linear correlation between two variables to be shown (Pradhan et al 2016 and Roy et al 2018).

\section{RESULTS AND DISCUSSIONS}

\section{Soil sample characteristic}

The main physical properties of the studied soil samples are shown in Table 2. The studied soil samples are classified into six (6) textural classes according to the USDA classification, with three represents light texture, i.e. Sandy, Loamy sand, and Sandy loam, which have high values of soil bulk density and $\mathrm{K}_{\text {sat. }}$ while have low value of total porosity. The other three represents heavy texture, i.e. Sandy clay loam, Silty clay loam, and Clay, with low values of both soil bulk density and the low saturated hydraulic conductivity. These results were agreed with (Bouma et al 2003; Bodner et al 2013 and Dettmann et al 2014).

Table 3 shows that the studied soil samples are poor in their content of organic matter (OM) and calcium carbonate. Also, results in Table 3 show that the studied soil samples have electrical conductivity (EC) values less than $4.0 \mathrm{dSm}^{-1}$, so they were classified as non-saline according to (Richard's, 1954). Subsequently, the concentrations of soluble cations and anions are low, where the obtained results of cations can be summarized as follow, the dominant soluble cations in most of soil samples is $\mathrm{Na}^{+}$which is followed by $\mathrm{Ca}^{2+}, \mathrm{Mg}^{2+}$ and $\mathrm{K}^{+}$, respectively. While, the dominant soluble anions are $\mathrm{Cl}^{-}$which is followed by $\mathrm{SO}_{4}{ }^{2-}, \mathrm{HCO}_{3}{ }^{-}$and $\mathrm{CO}_{3}{ }^{2-}$, respectively.

\section{Water retention data of the selected soil sam- ples}

Fig. (1) describes the measured volumetric soil water contents and their corresponding water pressures (h). Soil water content clearly decreases with the increase of suction, and this feature is mainly influenced by the distribution of particle size and pore size (El-Gendy, 2002). Regarding the effect of texture on the state of soil water in different soil samples, it can be said in general, that the finer textures have much greater total areas and much greater adsorption area, and therefore maintain a greater percentage of water at any pressure head (Hu et al 2013 and Iden et al 2015). 
Table 2. Some physics properties of the selected soil samples

\begin{tabular}{|c|c|c|c|c|c|c|c|c|c|}
\hline \multirow{2}{*}{ NO } & \multicolumn{4}{|c|}{ Particle size distribution \% } & \multirow{2}{*}{ Texture class } & \multirow{2}{*}{$\begin{array}{c}\rho_{\mathrm{b}} \\
\mathrm{g} \mathrm{cm}^{-3}\end{array}$} & \multirow{2}{*}{$\begin{array}{c}\rho_{\mathrm{s}} \\
\mathrm{g} \mathrm{cm}^{-3}\end{array}$} & \multirow{2}{*}{$f \%$} & \multirow{2}{*}{$\begin{array}{c}\mathrm{K}_{\text {sat }} \\
\mathrm{cm} \mathrm{s}^{-1}\end{array}$} \\
\hline & Coarse Sand & Fine Sand & Silt & Clay & & & & & \\
\hline 1 & 77.15 & 14.60 & 3.80 & 4.45 & Sand & 1.78 & 2.64 & 32.57 & 488.90 \\
\hline 2 & 64.60 & 22.20 & 2.80 & 10.40 & Loamy Sand & 1.66 & 2.58 & 35.65 & 129.35 \\
\hline 3 & 52.20 & 18.10 & 15.95 & 13.75 & Sandy Loam & 1.52 & 2.48 & 38.70 & 62.70 \\
\hline 4 & 6.60 & 50.40 & 14.30 & 28.70 & Sandy Clay loam & 1.38 & 2.60 & 46.92 & 11.55 \\
\hline 5 & 2.30 & 11.10 & 48.20 & 38.40 & Silty Clay Loam & 1.46 & 2.63 & 44.48 & 2.45 \\
\hline 6 & 9.35 & 19.85 & 28.20 & 42.60 & Clay & 1.23 & 2.67 & 53.93 & 1.89 \\
\hline
\end{tabular}

$\rho b$ is the soil bulk density. $\quad \rho s$ is the soil particle density.

$f$ is the soil total porosity. $\mathrm{K}_{\text {sat }}$ is the saturated soil hydraulic conductivity.

Table 3. Some chemical properties of the selected soil samples

\begin{tabular}{|c|c|c|c|c|c|c|c|c|c|c|c|c|}
\hline \multirow[t]{2}{*}{ NO } & \multirow{2}{*}{$\begin{array}{c}E_{e} \\
d S ~ m^{-1}\end{array}$} & \multirow[t]{2}{*}{ pH } & \multirow[t]{2}{*}{$\mathrm{CaCO}_{3} \%$} & \multirow{2}{*}{$\begin{array}{l}\text { OM } \\
\%\end{array}$} & \multicolumn{4}{|c|}{$\begin{array}{l}\text { Water soluble cations } \\
\text { meq L-1 }\end{array}$} & \multicolumn{4}{|c|}{$\begin{array}{c}\text { Water soluble anions } \\
\text { meq } L^{-1}\end{array}$} \\
\hline & & & & & $\mathbf{K}^{+}$ & $\mathrm{Na}^{+}$ & $\mathrm{Mg}^{2+}$ & $\mathrm{Ca}^{2+}$ & $\mathrm{Cl}^{-}$ & $\mathrm{SO}_{4}{ }^{2-}$ & $\mathrm{HCO}_{3}^{-}$ & $\mathrm{CO}_{3}{ }^{2-}$ \\
\hline 1 & 1.37 & 7.81 & 0.48 & 0.29 & 0.03 & 8.24 & 0.94 & 5.35 & 6.61 & 4.30 & 4.25 & nd \\
\hline 2 & 1.91 & 7.85 & 2.87 & 1.17 & 0.62 & 8.75 & 2.79 & 6.26 & 11.12 & 5.65 & 2.45 & nd \\
\hline 3 & 1.54 & 8.32 & 3.24 & 2.74 & 0.72 & 12.12 & 1.04 & 4.97 & 10.12 & 2.42 & 4.61 & nd \\
\hline 4 & 1.47 & 8.14 & 3.23 & 0.65 & 0.03 & 0.52 & 0.34 & 0.36 & 0.47 & 0.78 & 0.11 & nd \\
\hline 5 & 2.34 & 8.41 & 1.24 & 0.58 & 0.68 & 12.22 & 1.12 & 9.02 & 7.41 & 10.15 & 5.14 & nd \\
\hline 6 & 0.18 & 8.05 & 4.70 & 1.14 & 0.03 & 0.46 & 0.71 & 0.36 & 0.41 & 1.22 & 0.17 & nd \\
\hline
\end{tabular}

$\mathrm{nd}=$ Not detected

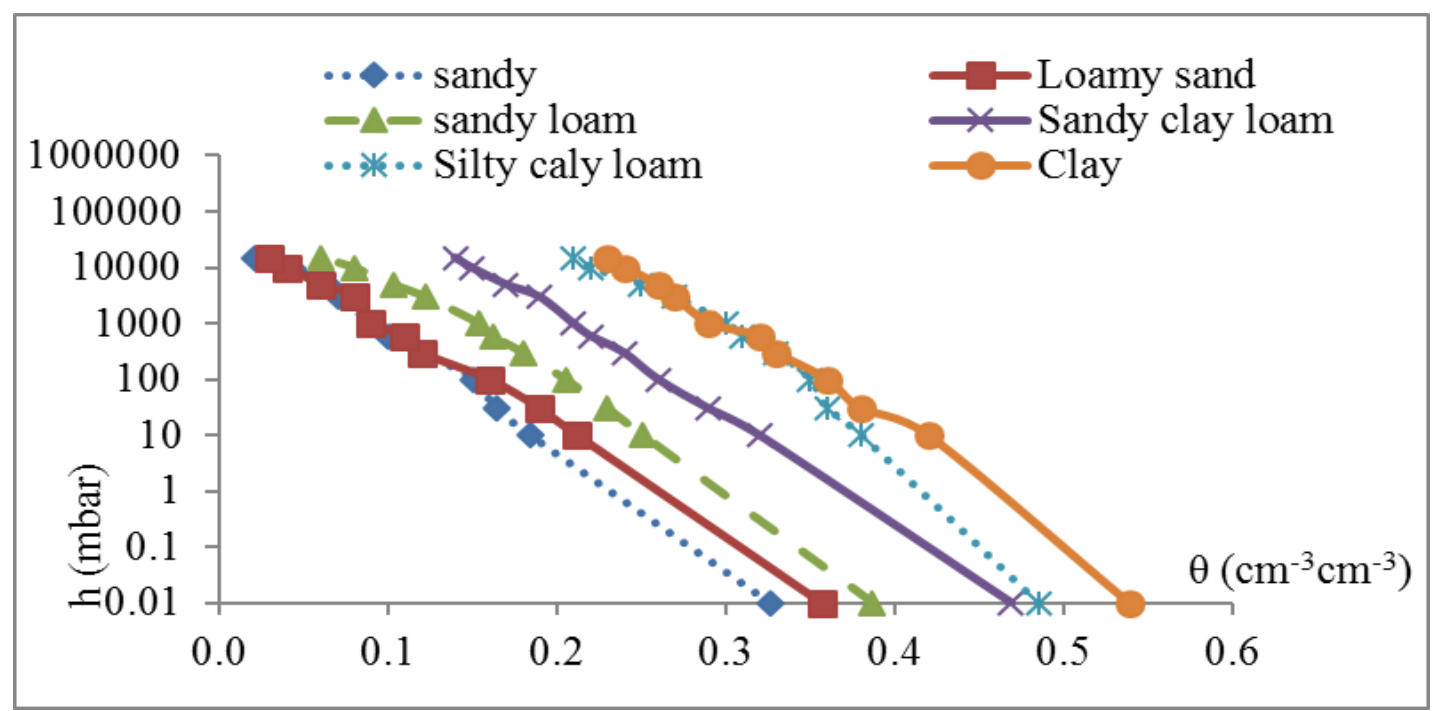

Fig. 1. Measured soil water retention curve 
Experimental, estimated and improved feature relationships $\boldsymbol{\theta}(\mathrm{h})$.

Soil water retention data, were obtained experimentally and used to get soil parameters of $\theta(h)$, $K(\theta)$ and $D(\theta)$ functions based on both $\mathbf{B}-\mathbf{C}$ and $\mathbf{v G}$ models. Estimated soil parameters of both $\mathbf{B}-\mathbf{C}$ and vG models subjected to refining process through RETC code running. Finally, estimated and refined values were used to get $\theta(h), K(\theta)$ and $D(\theta)$ functions based on both $\mathbf{B}-\mathbf{C}$ and $\mathbf{v G}$ models fitted as a power function.

Fallah et al 2015 and Xing et al 2018 stated that the popular power-function is the most general three-parameter model, since it gives a good fit to observations of $\theta(h)$ data over varying ranges of pressure head (h) and across a wide range of soil textures. Therefore, formulating the observed data as a power function give significant relationship between pressure head (mbar) and soil water content $\left(\mathrm{cm}^{-3} \mathrm{~cm}^{-3}\right)$ of the observed data of all the studied soil texture, Table (4a).

The values of determination coefficient $\left(R^{2}\right)$ of the fitted $\theta(\mathrm{h})$ as a power function are increased after fitting the experimental data either in B-C or in vG models. Table $4 a$ shows that $R^{2}$ of the fitted equation of $\theta(\mathrm{h})$ experimental data increased from 0.740 up to 0.8630 and 0.8940 for B-C and vG, respectively in sandy soil. The aforementioned results are clearly pronounced in all soil textural classes. The obtained results are in agreement with those obtained by Pradhan et al (2016), Borek and Bogdał (2018) and Londra and Kargas (2018).

Table $4 a$ also reveal that $R^{2}$ of the fitted equation of $\theta(h)$ of both $\mathbf{B}-\mathbf{C}$ and $\mathbf{v G}$ data increased after refining process through RETC code. The increase of $R^{2}$ values after refining are more pronounced in coarse textured samples (Sand, Loamy sand, and Sandy loam), Table $\mathbf{4 a}$. This finding may be due to that in heavy textured soils with complex pore network and lack of fitting because distribution poresize models assume water retained and flow through cylindrical soil pores.

As estimated values of both $K(\theta)$ and $D(\theta)$, also fitted as power functions with higher $R^{2}$, Table $4 \mathbf{b}$ and $c$.

The values of determination coefficient $\left(R^{2}\right)$ of the fitted $K(\theta)$ as a power function are highly signif icant after fitting water retention data either in B-C or in VG models. Data in Table $\mathbf{4 b}$ reveal that $R^{2}$ of the fitted equation ranged from 0.925 to 0.993 with B-C and ranged from 0.932 - 0.998 with vG and $R^{2}$ of the fitted equation ranged from 0.967 to 0.979 of B-C and from 0.997 to 0.999 of vG. The aforementioned results are clearly pronounced at all soil textural classes. The obtained results are in agreement with those obtained by Pradhan et al (2016), Borek and Bogdał, (2018) and Londra and Kargas (2018).

With regards to diffusivity of soil water $D(\theta)$, results in Table $4 \mathrm{c}$ shows that the values of determination coefficient $\left(R^{2}\right)$ of fitted $D(\theta)$ as a power function are highly significant after fitting water retention data either in B-C or in vG models. Results inTable $4 c$ reveal also that $R^{2}$ of the fitted equation ranged from 0.912 to 0.973 with $\mathbf{B}-\mathbf{C}$ and ranged from 0.920 to 0.953 with $\mathbf{v G}$ model.

The values of the determination coefficient $\left(R^{2}\right)$ of the fitted $D(\theta)$ as a power function are very highly significant after refining B-C and vG data using RETC code. Results in Table $4 c$ reveal also that $R^{2}$ of the fitted equation ranged from 0.979 to 0.994 of B-C and from 0.996 to 0.999 of vG. The aforementioned results are clearly pronounced at all soil textural classes (Pradhan et al 2016).

These findings are in perfect agreement with those of Kadhim (2011) who used the RETC code for predicting the hydraulic properties of the soil and found that van Genuchten model, Mualem $(m=1-1$ $/ \mathrm{n}$ ) is superior to others studied models with the highest determination coefficient $R^{2}=0.9843$.

As mentioned before, the model parameters are defined graphically by the parameter $\mathbf{b}=(\theta r, \theta s, \alpha$, $\mathrm{n}, \mathrm{m}, \mathrm{l}, \mathrm{Ks}$ ), which formulate the values of soil hydraulic properties for the used model, SSQ is referred to as the goal function $\mathbf{O}(\mathbf{b})$, where b represents the undefined vector parameter. By the weighted least square rule RETC also reduces $\mathbf{O}(\mathbf{b})$. The elements $\mathbf{b j}$ of the parameter vector $b$ are updated sequentially during each iteration step, and the model results are compared with those obtained at the previous iteration step up to get SSQ minimum.

In general, the RETC code is a good tool for obtaining accurate values of hydraulic properties in a variety of soil texture. 


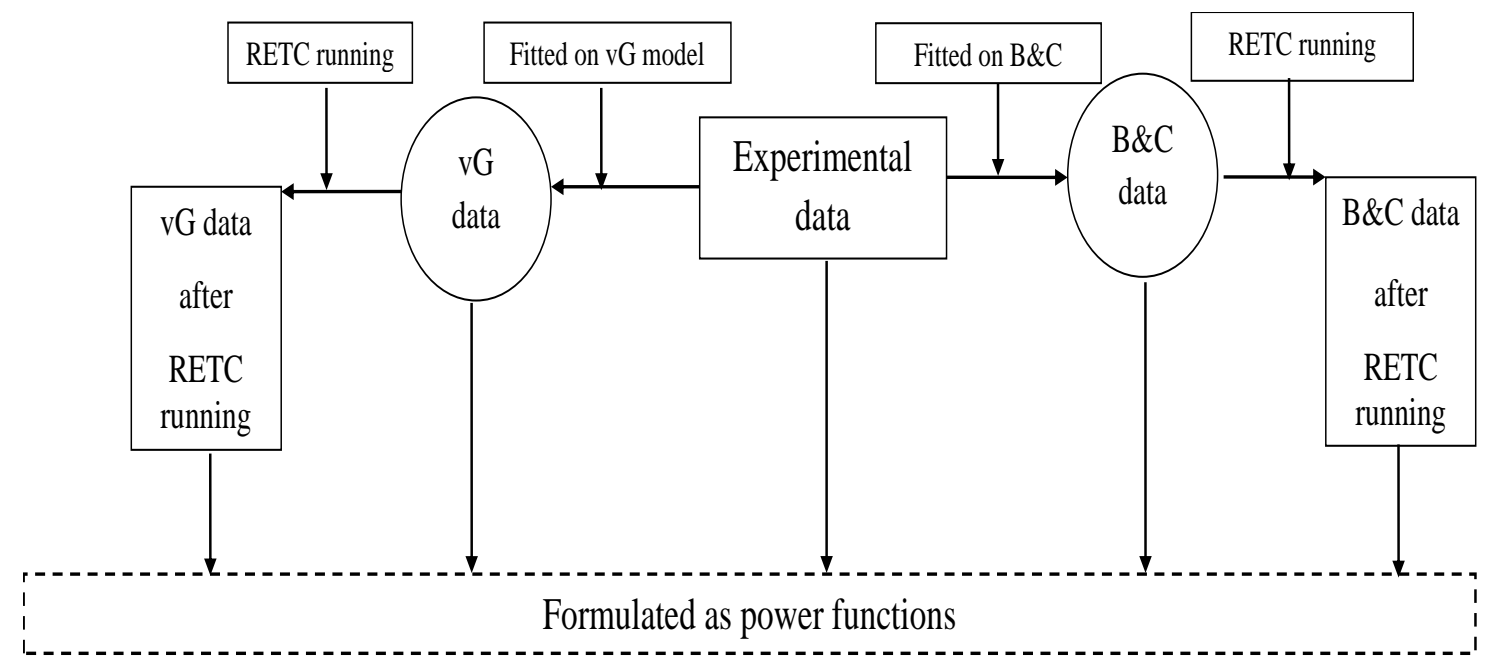

Table $4 \mathbf{a}, \mathbf{b}$ and $\mathbf{c}$. Formulated equations as a power function and their coefficient of determination of $\theta(\mathrm{h})$, $K(\theta)$ and $D(\theta)$ functions of the studied soil textural classes.

a) Functions of soil water retention $\theta(\mathrm{h})$

\begin{tabular}{|c|c|c|c|c|c|}
\hline $\begin{array}{c}\text { Textural } \\
\text { class }\end{array}$ & $\begin{array}{c}\text { Experimental } \\
\text { data } \\
\mathbf{R}^{2} \\
\end{array}$ & $\begin{array}{c}\text { vG data } \\
\mathbf{R}^{2}\end{array}$ & $\begin{array}{c}\text { vG after RETC } \\
\text { running } \\
\mathbf{R}^{2}\end{array}$ & $\begin{array}{c}\text { B\&C data } \\
\mathbf{R}^{2}\end{array}$ & $\begin{array}{c}\text { B\&C after RETC } \\
\text { running } \\
\mathbf{R}^{2}\end{array}$ \\
\hline \multirow[t]{2}{*}{ Sand } & $y=0.0032 x^{-4.79}$ & $y=0.0002 x^{-5.62}$ & $y=4 E-05 x^{-6.83}$ & $y=0.0002 x^{-5.35}$ & $y=4 E-05 x^{-6.87}$ \\
\hline & $\mathrm{R}^{2}=0.782$ & $\mathrm{R}^{2}=0.894$ & $R^{2}=0.942$ & $\mathrm{R}^{2}=0.863$ & $\mathrm{R}^{2}=0.943$ \\
\hline \multirow[t]{2}{*}{ Loamy sand } & $y=0.0026 x^{-5.04}$ & $y=0.0001 x^{-6.04}$ & $y=0.0002 x^{-6.35}$ & $y=0.0001 x^{-5.94}$ & $y=0.0002 x^{-6.41}$ \\
\hline & $\mathrm{R}^{2}=0.833$ & $\mathrm{R}^{2}=0.881$ & $\mathrm{R}^{2}=0.975$ & $\mathrm{R}^{2}=0.871$ & $\mathrm{R}^{2}=0.928$ \\
\hline \multirow[t]{2}{*}{ Sandy loam } & $y=0.004 x^{-6.14}$ & $y=0.0001 x^{-7.59}$ & $y=9 E-05 x^{-8.54}$ & $y=0.0001 x^{-7.32}$ & $y=0.0001 x^{-7.82}$ \\
\hline & $\mathrm{R}^{2}=0.740$ & $\mathrm{R}^{2}=0.834$ & $\mathrm{R}^{2}=0.975$ & $R^{2}=0.816$ & $\mathrm{R}^{2}=0.941$ \\
\hline Sandy clay & $y=1 E-05 x^{-11.2}$ & $y=4 E-06 x^{-11.9}$ & $y=7 E-06 x^{-11.7}$ & $y=2 E-05 x^{-10.9}$ & $y=6 E-06 x^{-11.8}$ \\
\hline loam & $\mathrm{R}^{2}=0.844$ & $\mathrm{R}^{2}=0.945$ & $R^{2}=0.987$ & $\mathrm{R}^{2}=0.946$ & $\mathrm{R}^{2}=0.967$ \\
\hline Silty clay & $y=1 E-06 x^{-15.8}$ & $y=2 E-06 x^{-15.2}$ & $y=2 E-07 x^{-17.6}$ & $y=8 E-06 x^{-14.2}$ & $y=4 E-07 x^{-16.9}$ \\
\hline loam & $\mathrm{R}^{2}=0.823$ & $\mathrm{R}^{2}=0.842$ & $R^{2}=0.894$ & $\mathrm{R}^{2}=0.826$ & $\mathrm{R}^{2}=0.863$ \\
\hline \multirow[t]{2}{*}{ Clay } & $y=6 E-06 x^{-15.3}$ & $y=3 E-06 x^{-16.2}$ & $y=4 E-06 x^{-15.7}$ & $y=3 E-06 x^{-16.3}$ & $y=4 E-06 x^{-15.7}$ \\
\hline & $R^{2}=0.844$ & $\mathrm{R}^{2}=0.977$ & $\mathrm{R}^{2}=0.986$ & $R^{2}=0.946$ & $\mathrm{R}^{2}=0.956$ \\
\hline
\end{tabular}


b) Functions of unsaturated hydraulic conductivity $K(\theta)$

\begin{tabular}{|c|c|c|c|c|}
\hline Textural class & $\begin{array}{c}\text { vG data } \\
\mathbf{R}^{2}\end{array}$ & $\begin{array}{c}\text { vG after RETC } \\
\text { running } \\
\mathbf{R}^{2} \\
\end{array}$ & $\begin{array}{c}\text { B\&C data } \\
\mathbf{R}^{2}\end{array}$ & $\begin{array}{c}\text { B\&C after RETC } \\
\text { running } \\
\mathbf{R}^{2}\end{array}$ \\
\hline \multirow[t]{2}{*}{ Sand } & $y=9 E+9 x^{13.53}$ & $y=4 E+6 x^{13.44}$ & $y=1 E+08 x^{13.06}$ & $y=2 E+7 x^{12.32}$ \\
\hline & $\mathrm{R}^{2}=0.932$ & $R^{2}=0.998$ & $\mathrm{R}^{2}=0.925$ & $\mathrm{R}^{2}=0.969$ \\
\hline \multirow[t]{2}{*}{ Loamy sand } & $y=3 E+08 x^{13.57}$ & $y=29559 x^{12.49}$ & $y=9 E+06 x^{13.40}$ & $y=74844 x^{11.38}$ \\
\hline & $\mathrm{R}^{2}=0.968$ & $R^{2}=0.999$ & $\mathrm{R}^{2}=0.966$ & $R^{2}=0.969$ \\
\hline \multirow[t]{2}{*}{ Sandy loam } & $y=5 E+06 x^{16.47}$ & $y=41468 x^{22.19}$ & $y=26145 x^{14.95}$ & $y=3 E+06 x^{20.83}$ \\
\hline & $\mathrm{R}^{2}=0.997$ & $\mathrm{R}^{2}=0.999$ & $\mathrm{R}^{2}=0.979$ & $\mathrm{R}^{2}=0.987$ \\
\hline \multirow[t]{2}{*}{ Sandy clay loam } & $y=5 E+07 x^{15.13}$ & $y=37446 x^{15.22}$ & $y=92150 x^{14.73}$ & $y=3 E+06 x^{12.76}$ \\
\hline & $\mathrm{R}^{2}=0.992$ & $R^{2}=0.997$ & $R^{2}=0.967$ & $\mathrm{R}^{2}=0.989$ \\
\hline \multirow[t]{2}{*}{ Silty clay loam } & $y=2 E+09 x^{24.89}$ & $y=1 E+07 x^{28.58}$ & $y=9 E+06 x^{23.49}$ & $y=9 E+07 x^{21.79}$ \\
\hline & $\mathrm{R}^{2}=0.993$ & $\mathrm{R}^{2}=0.998$ & $R^{2}=0.963$ & $\mathrm{R}^{2}=0.992$ \\
\hline \multirow[t]{2}{*}{ Clay } & $y=3 E+07 x^{24.27}$ & $y=75678 x^{28.2}$ & $y=1 E+06 x^{24.40}$ & $y=94611 x^{26.81}$ \\
\hline & $\mathrm{R}^{2}=0.982$ & $R^{2}=0.998$ & $R^{2}=0.939$ & $\mathrm{R}^{2}=0.979$ \\
\hline
\end{tabular}

c) Functions of soil water diffusivity $D(\theta)$

\begin{tabular}{|c|c|c|c|c|}
\hline Textural class & $\begin{array}{c}\text { vG data } \\
\mathbf{R}^{2}\end{array}$ & $\begin{array}{c}\text { vG after RETC } \\
\text { running } \\
\mathbf{R}^{2} \\
\end{array}$ & $\begin{array}{c}\text { B\&C data } \\
\mathbf{R}^{2}\end{array}$ & $\begin{array}{c}\text { B\&C after RETC } \\
\text { running } \\
\mathbf{R}^{2} \\
\end{array}$ \\
\hline \multirow[t]{2}{*}{ Sand } & $y=4088 x^{4.17}$ & $y=55072 x^{7.16}$ & $y=13463 x^{3.17}$ & $y=16068 x^{5.86}$ \\
\hline & $R^{2}=0.953$ & $R^{2}=0.999$ & $\mathrm{R}^{2}=0.973$ & $R^{2}=0.992$ \\
\hline \multirow[t]{2}{*}{ Loamy sand } & $y=485.5 x^{4.09}$ & $y=13670 x^{6.68}$ & $y=12944 x^{3.81}$ & $y=22076 x^{5.40}$ \\
\hline & $R^{2}=0.949$ & $\mathrm{R}^{2}=0.998$ & $\mathrm{R}^{2}=0.962$ & $R^{2}=0.994$ \\
\hline \multirow[t]{2}{*}{ Sandy loam } & $y=258.0 x^{5.05}$ & $y=23564 x^{8.04}$ & $y=1433 x^{3.35}$ & $y=39144 x^{6.06}$ \\
\hline & $\mathrm{R}^{2}=0.935$ & $\mathrm{R}^{2}=0.999$ & $\mathrm{R}^{2}=0.912$ & $R^{2}=0.987$ \\
\hline \multirow[t]{2}{*}{ Sandy clay loam } & $y=36.63 x^{9.23}$ & $y=841.1 x^{11.55}$ & $y=384.3 x^{9.75}$ & $y=5627 x^{10.14}$ \\
\hline & $R^{2}=0.920$ & $R^{2}=0.996$ & $R^{2}=0.946$ & $\mathrm{R}^{2}=0.989$ \\
\hline \multirow[t]{2}{*}{ Silty clay loam } & $y=13.68 x^{8.47}$ & $y=14514 x^{14.76}$ & $y=35.76 x^{7.14}$ & $y=3 E+06 x^{10.64}$ \\
\hline & $R^{2}=0.95$ & $\mathrm{R}^{2}=0.997$ & $\mathrm{R}^{2}=0.926$ & $R^{2}=0.979$ \\
\hline \multirow[t]{2}{*}{ Clay } & $Y=10.10 x^{12.19}$ & $y=180.8 x^{14.56}$ & $y=12.75 x^{11.14}$ & $y=2257 x^{13.15}$ \\
\hline & $\mathrm{R}^{2}=0.932$ & $\mathrm{R}^{2}=0.996$ & $\mathrm{R}^{2}=0.946$ & $\mathrm{R}^{2}=0.988$ \\
\hline
\end{tabular}

\section{CONCLUSIONS}

Due to temporal and spatial soil variability, direct measurement of soil hydraulic properties became uncertain. To get accurate values of these properties, modeling estimation and computer codes (e.g., RETC code) have been used. Hydraulic properties (theta, K, D) of six different textured Egyptian soils were studied by the RETC code based on measured water retention data and Ksat. Fitting performances of van Genuchten and Brooks-Corey equations with a combination of the Mualem pore-size distribution model were compared. Then, a threeparameter power function was utilized to fit the RETC- smoothed data. In this study, both Brooks \& Corey (1964) and van Genuchten (1980) models 
were used to fit the experimental data of soil hydraulic properties to increase the accuracy of estimation and then formulated as a power function. Generally, the exponents of power functions were higher of the equations of coarse-textured soils - sand, Loamy sand, and sandy loam - followed by medium - Sandy clay loam - and heavy-textured ones. The value of the exponent of power function was more sensitive to using RETC than its coefficient. The RETC code was used to match the parameters of the model and simultaneously to the observed data to increase the performance data from these above-mentioned models. The values of the determination coefficient $\left(R^{2}\right)$ increased after fitting the experimental data either in $\mathbf{B}-\mathbf{C}$ or in vG models. The values of $R^{2}$ of the fitted equations with both B-C and VG data increased after the refining process through RETC code. These increments of $R^{2}$ values after refining are more pronounced in coarse-textured samples than in heavy-textured ones.

\section{REFERENCES}

Bodner G., Scholl P., Loiskandl W. and Kaul H.P. 2013. Environmental and management influences on temporal variability of near saturated soil hydraulic properties. Geoderma, 204, 120129.

Bohne K., Zacharias S. and Wessolek G. 2000. Testing of three methods to predict unsaturated soil hydraulic conductivity from water retention data or from the soil type. J. of Plant Nutrition and Soil Sci., 163, 7-12.

Borek Ł. and Bogdał A. 2018. Soil water retention of the Odra River alluvial soils (Poland): Estimating parameters by RETC model and laboratory measurements. Applied Ecology and Environmental Research, 16, 4681-4699.

Bouma J.L., Aronson L.R., Keith D.G. and Mark S.H. 2003. Use of computed tomography renal angiography for screening feline renal transplant donors. Veterinary Radiology \& Ultrasound, 44, 636-641.

Brooks R.H. and Corey A.T. 1964. Hydraulic properties of porous media. Hydrol. Colorado State Univ., Fort Collins., 21, 1183-1226.

Burdine N. 1953. Relative permeability calculations from pore size distribution data. J. of Petroleum Technology, 5, 71-78.

Dettmann U., Bechtold M., Frahm E., and Tiemeyer B. 2014. On the applicability of unimodal and bimodal van Genuchten-Mualem based models to peat and other organic soils un- der evaporation conditions. J. of Hydrology, 515, 103-115.

El-Gendy R.W. 2002. Estimating unsaturated hydraulic conductivity from soil moisture-tim function. Arab J. of Nuclear Sci. and Applications, 35, 189-202.

Fallah M., Shabanpor M. and Ebrahimi S. 2015. Evaluation of petroleum impacts on some properties of loamy sand soil with the main focus on hydraulic properties. Environmental Earth Sci., 74, 4751-4762.

Gimenez D., Rawls W.J., Pachepsky Y. and Watt J.P.C. 2001. Prediction of a pore distribution factor from soil textural and mechanical parameters. Soil Science, 166, 79-88.

Hu R., Chen Y.F., Liu H.H. and Zhou C.B. 2013. A water retention curve and unsaturated hydraulic conductivity model for deformable soils: consideration of the change in pore-size distribution. Géotechnique, 63, 1389-1405.

Iden S.C., Peters A. and Durner W. 2015. Improving prediction of hydraulic conductivity by constraining capillary bundle models to a maximum pore size. Advances in Water Resources, 85, 86-92.

Kadhim A.J. 2011. Expansion Methods for Solving Linear Integral Equations with Multiple Time Lags Using B-Spline and Orthogonal Functions. Engineering and Technology J., 29, 1651-1661.

Klute A. 1986. Water retention: laboratory methods. Methods of soil analysis: Part 1-physical and Mineralogical Mthods, 5, 635-662.

Londra P. and Kargas G. 2018. Evaluation of hydrodynamic characteristics of porous media from one-step outflow experiments using RETC code. J. of Hydroinformatics, 20, 699-707.

Mualem Y. 1976. A new model for predicting the hydraulic conductivity of unsaturated porous media. Water Resources Research, 12, 513-522.

Nasta P., Vrugt J.A. and Romano N. 2013. Prediction of the saturated hydraulic conductivity from Brooks and Corey's water retention parameters. Water Resources Research, 49, 29182925.

Nguyen P. 2016. Development and evaluation of soil water retention pedotransfer functions for Mekong Delta soils in Vietnam Doctoral dissertation, Ghent Univ., Beigium, 7, 135-169.

Page A.L., Miller R.H. and Keeney D.R. 1982. Methods of soil analysis. Part 1. Physical and Mineralogical Methods. ASA and SSSA: Madison, WI., USA, pp. 403-430. 
Patil N.G. and Singh S.K. 2016. Pedotransfer functions for estimating soil hydraulic properties: A review. Pedosphere, 26, 417-430.

Pradhan S., Gorai T., Ahmed N., Bandyopadhyay K.K., Sahoo R.N., Mahapatra S.K. and Singh R. 2016. Estimating S-index, unsaturated hydraulic conductivity and diffusivity through RETC in Indian Agricultural Research Institute farm. J. of the Indian Society of Soil Sci., 64, 120-127.

Richards L.A. 1954. Diagnosis and Improvement of saline and alkali soils. US. Dept. Agric. Handbook, 2, 60-78.

Roy D., Jia X., Steele D.D. and Lin D. 2018. Development and comparison of soil water release curves for three soils in the red river valley. Soil Sci. Society of America J., 82, 568577.
Schindler U., von Unold G., Durner W. and Mueller L. 2015. April. Recent progress in measuring soil hydraulic properties. In Proceedings of the International Conference on Environment and Civil Engineering, pp. 2425.

Soldi M., Guarracino L. and Jougnot D. 2017. A simple hysteretic constitutive model for unsaturated flow. Transport in Porous Media, 120, 271-285.

Van Genuchten M.T. 1980. A closed-form equation for predicting the hydraulic conductivity of unsaturated soils 1. Soil Sci. Society of America J., 44, 892-898.

Xing X., Wang H. and Ma X. 2018. Brooks-Corey Modeling by One-Dimensional Vertical Infiltration Method. Water, 10, 593-603.

Yates S.R., Van Genuchten M.T., Warrick A.W. and Leij F.J. 1992. Analysis of measured, predicted, and estimated hydraulic conductivity using the RETC computer program. Soil Sci. Society of America J., 56, 347-354. 


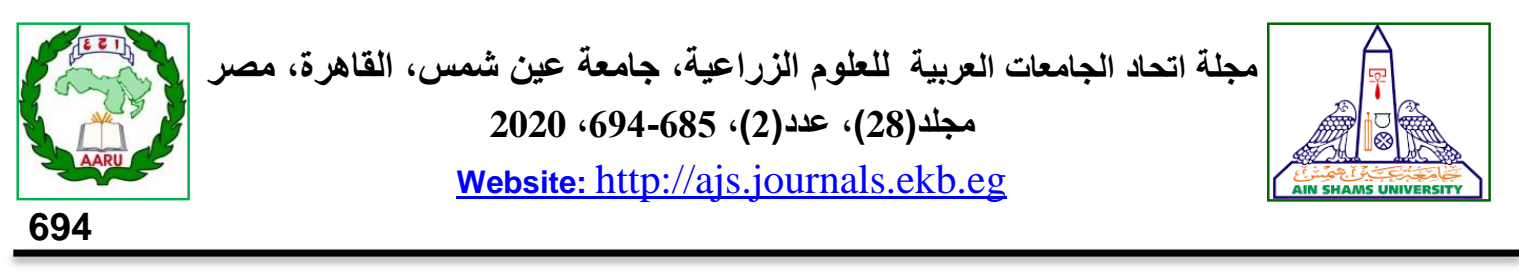

تحديد الخصائص الهيروليكية لبعض الأراضى المصرية بإستخدام RETC code

[51]

$$
\begin{aligned}
& \text { أحمد ايهاب طلعت1" - أحمد عادل سعد الدين } 1 \text { - ياسر عزت عرفه² - محمد السيد جلال1 } 1
\end{aligned}
$$

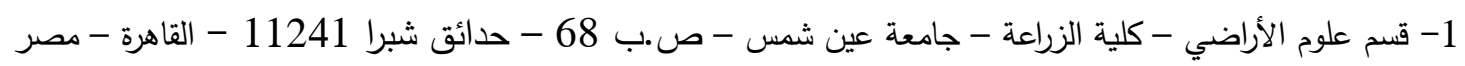

$$
\begin{aligned}
& \text { 2- قسم الهنسة الزراعية - كلية الزراعة - جامعة عين شمس - صلب } 68 \text { - حدائق شبرا } 11241 \text { - القاهرة - مصر تُبر } \\
& \text { *Corresponding author: ahmed ehab2257@yahoo.com }
\end{aligned}
$$

Received 12 May, 2020

Accepted 5 July, 2020

عملية تكرار التحليل الإحصائي ومستويات التكرار

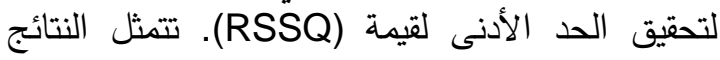

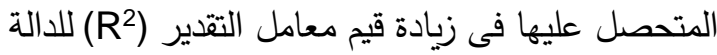
عند توفيق الدالة (h) $\theta$ كدالة قوى بعد توفيق البيانات

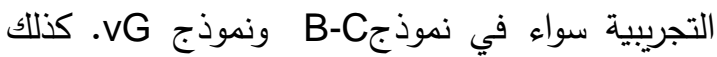

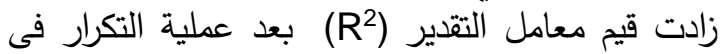

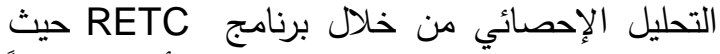

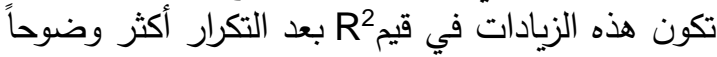

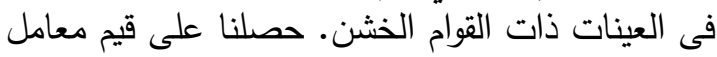

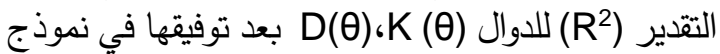

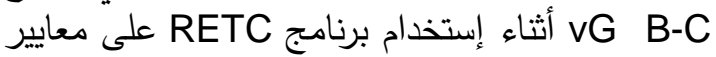

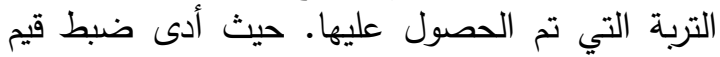

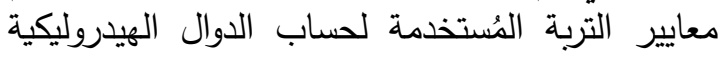

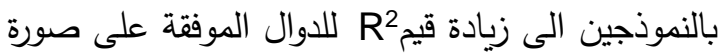

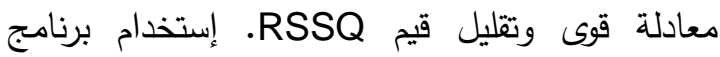
خفض قيمة (RSSQ RETC المستهدفة (b) تحت ظروف إستخدام كل من نموذج لخدير B-C, vG RETC

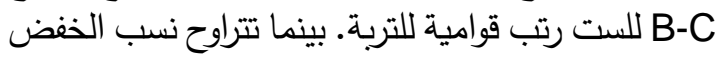

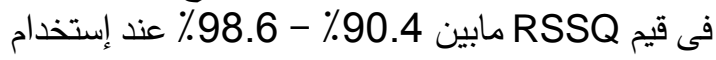

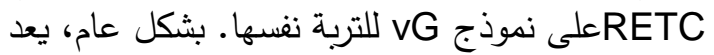

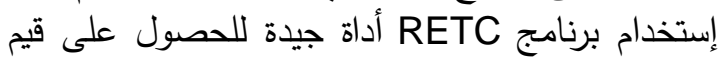
دقيقة للخواص الهيدروليكية.

الكلمات المفتاحية: الخواص الهيدروليكية للتربة، منحنى الرئي الثد الرطوبى للتربة، التوصيل الهيدروليكي، RETC

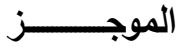

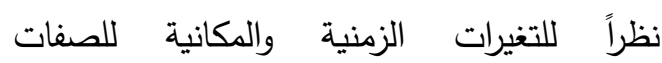

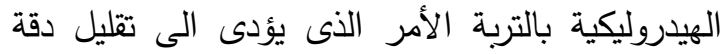

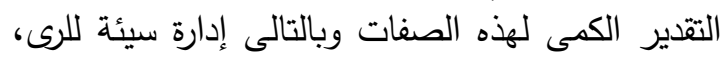

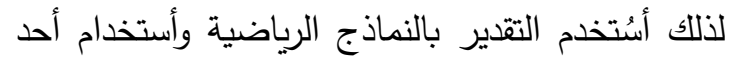

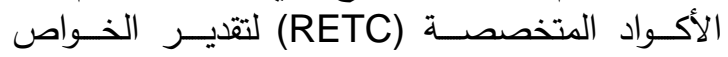

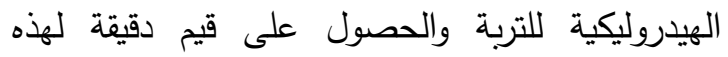

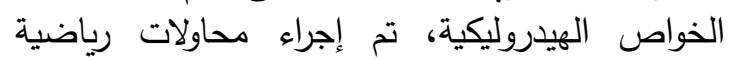

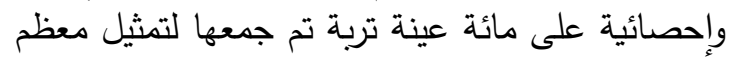

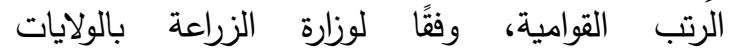

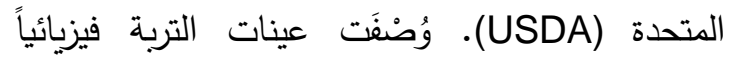

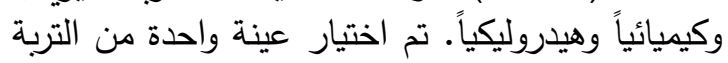

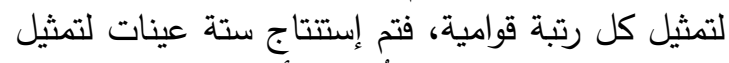

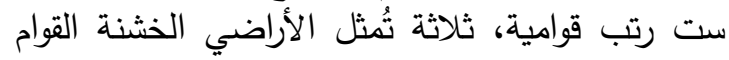

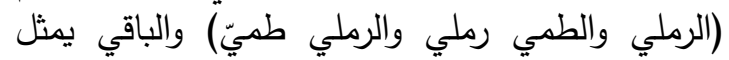
الأراضي ناعمة القوام (الطيني والسلتيطيني طيني ولتيني والرمليطيني طميّ). بيانات الثُد "الرطوبى بالتربة (h)

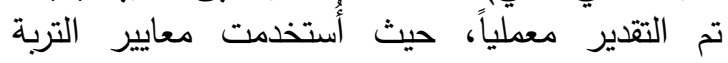

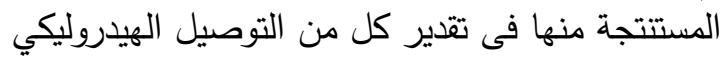

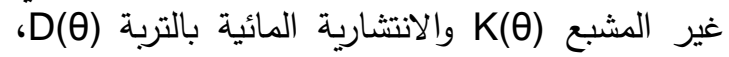

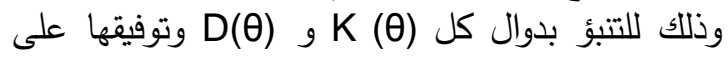

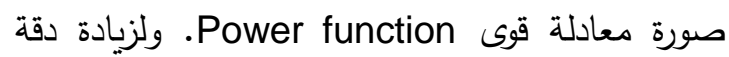
بيانات مخرجات هذه النماذج، تم إستخدام نموذج

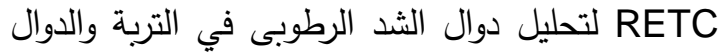

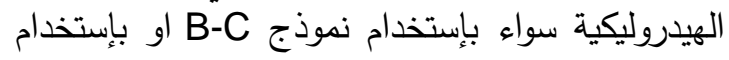

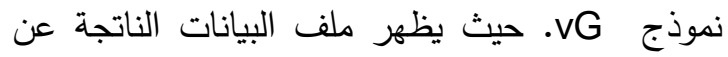

